\title{
Introduction: CSR Agendas for Asia
}

Wendy Chapple and Jeremy Moon

Received 25 January 2007; revised 28 April 2007; accepted 20 May 2007

Keywords: corporate social responsibility; Asia; globalization; research agenda; national business systems

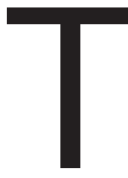

HE PAPERS COLLECTED IN THIS SPECIAL ISSUE HAVE BEEN SELECTED FROM THOSE PRESENTED at the second ICCSR CSR in Asia conference held in Kuala Lumpur in April 2006. 'They offer a wide range of issues and disciplinary approaches, with a focus on corporate social responsibility (CSR) in the Asian region. The study of CSR in Asia is an important but relatively under-researched area. We hope that the conference and this special issue will add to the momentum of this growing field.

As noted by The Economist (2005), 'CSR has blossomed as an idea'. However, as The Economist also noted, there is uncertainty about what CSR is, in both the general and the specific contexts. This is something that researchers have sought to rectify, particularly in respect of CSR in North America and Western Europe. As part of this process, there has been a proliferation of terms that have emerged to capture the business such as corporate social responsibility (Wood, I991; Carroll, I979), corporate citizenship (Moon et al., 2004) and sustainability (Welford, I997), which have all been developed in the context of the western world. Many concepts have emerged to capture the impacts and interaction between globalization and multinational enterprises' CSR activities. Global citizenship (Logsdon and Wood, 2005) is constructed around concepts or codes, orientation, styles of implementation and accountability, combining multi-domestic strategies with globally integrated strategies (Bartlett and Ghoshal, I989). However, even this principle is still focussed on US principles of the role of business in society and is essentially looking at how these are exported to various locations around the world, rather than understanding how CSR is manifesting itself and evolving in culturally and institutionally diverse settings.

When the ICCSR held its first CSR in Asia conference in 2003 there was very little research available. Many of the CSR concepts and tools derive from western ideas and practices. Yet Asian business systems have a variety of their own norms and practices for CSR. Some are long-standing and embedded, reflecting wider institutional and cultural phenomena, and others relatively new, reflecting adjustments to globalization. Asian societies also yield some very different CSR contexts and challenges, such as poverty and wealth distribution, labour rates and standards, educational disparities, civil society organizations, bases of governmental power and legitimacy, corporate governance challenges, access to water and a vulnerability to natural disasters. Notwithstanding the increasing inter-connection of Asian and Western economies, societies and environments, these factors remain true. However, there has been an increase in research on the CSR in Asia specifically in order to identify the nature and significance of these differences. This journal regularly devotes sections of individual issues to CSR in Asia and our special collection seeks to contribute further to this growing body of knowledge.

\section{Theoretical Approaches to Studying CSR in Asia}

Lockett et al. (2006) found that CSR is not a discipline and is better described as a field of research (Lockett et al., 2006). Therefore CSR relies on wider disciplines for theories and methodologies, but also provides an opportunity for theory development and evolution.

\footnotetext{
* Correspondence to: Wendy Chapple, International Centre for Corporate Social Responsibility, Nottingham University Business School, Jubilee Campus, Nottingham, NG8 1BB. Tel.: + 44 (0) 115951 4781, Fax: + 44 (o) 1158468074 . E-mail: Wendy.Chapple@nottingham.ac.uk

${ }^{\mathrm{I}}$ A collection from the first ICCSR CSR in Asia conference was edited by Birch and Moon (2004). 
As a permeable field, there are a number of research traditions which can be applied to CSR, and as yet there has not been a consensus in terms of CSR theory; hence, as in the entrepreneurship field, empirical work is essential for CSR theory building (Eisenhardt, I989). However, unlike entrepreneurship, theoretical convergence may be hindered by the political and social underpinnings of the construction of CSR. More particularly, cross-national studies bring different stakeholder expectations of business and different historical business roles in society. As Lockett et al. find, CSR in general is in a 'continual state of emergence'; there is a high profile but low domination of a particular theoretical approach, assumptions and method. To date, notwithstanding some notable exceptions, not only has much research on CSR in Asia been under-theorized but also the empirical research has not been addressed to the task of theory-building. Two points are therefore worth underlining. First, empirical research is most valuable when it is directed at theory-building. Second, there are opportunities to 'import' core disciplines into the study of CSR. These approaches to research in combination might act as a catalyst to move beyond the descriptive 'what is' research to more theory building and to addressing the 'why', 'how' and 'should' style questions about CSR in Asia.

\section{CSR in Asia: the Research Agenda}

\section{Across Countries: Within Multinationals}

There has been much discussion, particularly with regard to Asia, as to differences in the behaviour of multi-national corporations (MNCs) within the MNC (i.e. differences in behaviour between countries) or between MNCs and domestic companies. Some argue that the whole economics of globalization necessarily leads to irresponsibility, and in particular the exploitation of lax social and environmental standards and weak governance (Strike et al., 2006; Low and Yeats, I992; Lucas et al., I992). Chapple et al. (2006) propose this stance as an initial null hypothesis, but find no empirical evidence to support this. Alternatively, others argue there is a positive relationship between international diversification and social responsibility, and it is the international firms that transfer best practice (Bansal and Roth, 2000; Christmann, 2004). It is also argued that it is these firms that have the power and the resources to promote CSR, and hence MNCs could promote social justice (Bansal and Roth, 2000). However, others argue that it is not so polarized; Strike et al. (2006) argue that some firms can be responsible in some activities and irresponsible in others (e.g. Nike). Chapple et al. (2006) found that globalization/ internationalization of companies did in fact improve CSR relative to domestic firms in various Asian countries; however, there was still room for further improvement and there was high variance in CSR initiatives between countries. However, it was found that in terms of the CSR issues engaged with the MNCs were in fact adapting themselves to multiple local environments.

In general, little is known about the management of CSR in MNCs, either academically or practically. MNCs often struggle with the global verses local issues, and the tensions that emerge from the various demands at these levels. They formulate many of their policies at head office and, as a result, policies are shaped by institutional settings, stakeholder pressures and corporate governance mechanisms of their home country. However, this often creates tension, as these may be informed by very different ethical norms, histories and traditional roles of business in society in countries of operation. Again this raises interesting questions for MNCs in the Asian context.

The dominant theoretical approach to studying MNC CSR practices is that of the extended typology of Bartlett and Ghoshal (I989) and Prahalad and Doz (I987), which has been applied within the international business domain to analyse general MNC management practices. This framework was then extended by Yip (I992) and Husted and Allen (2006) to cover CSR practices. The underlying theory 
point is that CSR is not unlike any other organizational strategy, in that MNCs adopt multi-domestic, trans-national or global approaches to management. It follows then that CSR approaches and strategies vary according to whether CSR is institutionally driven or strategically managed. If, within the MNC, CSR is institutionally driven, one would expect institutional isomorphism within the firm to create consistency in approaches. If on the other hand CSR is treated strategically, CSR activities would be contingent on relative demands of local and global stakeholders. These theories can therefore inform research both within firms (detailed case studies) and across firms (cross-firm comparisons using firm level data). This would enable interesting insights into the operation of MNCs across Asia, and analysis of how CSR is being managed, how conflicts are resolved, the democratization of CSR practices and the potential barriers to the successful operationalization of CSR policies.

\section{Within Countries: National Business Systems}

Much of the research on CSR in Asia to date has focussed on the issue of the environment, primarily due to its long standing policy and stakeholder significance and company policies for either environmental responsibility or sustainability (Perry and Singh, 2002). However, when the term sustainability has been used, there has tended to be less discussion of the social and economic components (Viere et al., 2006). Within the Asian context, much of the work has been describing the governance aspects of environmental responsibility (Hong Kong; Hills and Welford, 2006; China; Bi et al., 2006; Thailand and the Philippines; Forsyth, 2005). In contrast, Mohan (200I) focused on the social responsibilities, or corporate citizenship, in India.

There has also been research into more normative aspects of Asian national business: in India (Chakraborty, I997), the Philippines (Sison et al., I997) and, interestingly, the evolution of business ethics in Taiwanese companies operating in Indonesia (Wu, 200I). In China, Snell et al. (2002) analysed the components 'moral atmosphere' and 'moral influence' within the emerging form of China's national business system, network capitalism. Snell et al. found that foreign invested joint venture companies (JVCs) had a more effective approach to formal moral governance. This was attributed to the adoption of foreign partners' systems, procedures and, in particular, the systems and norms of rational legal administration and internal justice. Other forms of organization, such as state owned and newly privatized companies, were struggling with moral authority issues, using systems of hierarchy and command to try and deal with moral justice issues.

In a study of CSR reporting in Malaysia, Teoh and Thong found that in all companies included in the study there was a general emphasis on human resources and product and services as a major area of corporate involvement - irrespective of national origin. There was less focus on community or environment. However, companies with foreign ownership seemed more inclined to accept their responsibilities. The analysis by Fukukawa and Moon (2004) of reporting in Japan found that companies reflected a key aspect of the national system in adopting the template for environmental reporting as suggested by the responsible government ministry.

Kemp (200I) found that the economic crisis in Indonesia not only damaged the national economic performance but also the social and legal factors crucial to CSR, resulting in instability, fear and violence. In such a context, CSR was reduced to an abstract ideal. However, he argued that institutions and educational foundations for CSR could evolve, but that they should be 'home grown' rather than imported. Also, he highlights that certain sectors engage in CSR and this makes a difference in terms of human rights of those working in these companies, but in other industries where the pressure is absent there is still poor CSR performance. He also raises issues as to whether CSR is the sole answer to exploitation, environmental degradation and poor labour standards - or whether relying on codes of conduct: civil society, government capacity and monitoring are all required. 


\section{Between Countries}

There has been a growing number of studies that have started to compare differences in CSR between countries (Matten and Moon, 2008; Habisch et al., 2004; Maignon and Ralston, 2002; Aguilera et al., 2007; Campbell, 2007). However, the focus of this research has tended to focus on Europe versus the US (Matten and Moon, 2008) or the situation within Europe (Habisch et al., 2004) or within OECD countries (Maignan and Ralston, 2002; Aguilera et al., 2007; Chapple et al., 2006). These studies tend to take a multi-level approach to the analysis, controlling for levels ranging from the individual up to trans-national levels. These theories in essence are separating out national institutional systems and norms from organizational factors. This approach is useful in understanding how certain aspects of national business systems or institutional contexts can influence the development of both the issues and the modes of CSR engagement. More importantly, this style of research also highlights the implications of 'missing' institutional factors (e.g. non-free press, low civil society engagement) in the evolution of CSR activities.

To date there has been limited analysis in the Asian context. Notable exceptions include Welford (2004; 2005) and Chapple and Moon (2005), who specifically look across Asian countries. Findings from both of these papers suggest lower levels of CSR in Asia than western counterparts, with the exception of Japan. Also found in both of these papers that CSR was very much tied to localized issues, cultural traditions at a country level, and historical events, resulting in heterogeneous CSR activities. However, further research is required to understand more deeply how these factors influence CSR both at the firm level and the national level. More detailed analysis is needed of what instrumental, moral and relational motives exist in national systems very different to the western contexts in which they were developed. The papers in this special issue by Baughn et al. and Zinkin start to address these questions in very different ways.

\section{Managerial Approaches}

In a study by Lines (2004), surveying CEO attitudes towards corporate reputation, it was found that Asian executives were much more focused on using corporate reputation to drive tangible business benefit than North American or European peers. It was found that CSR and the broader stakeholders did not feature strongly in the corporate reputation agenda of Asian executives; their prime focus was customer and shareholders rather than broader stakeholder groups. This raises interesting questions in terms of the role of leadership, training and experience in the development of CSR and how different backgrounds of CEOs influence CSR activities. As a side note it is interesting to see that despite community being one of the main CSR beneficiaries in Asia (Chapple and Moon, 2005), the CEOs do not perceive this as an important part of reputation management, which suggests other motives, such as development, capacity building or believing it is the right thing to do.

In a separate study, Abdul and Ibrahim (2002) found that in Malaysia 69\% of executives believed that involvement of a business in community focused CSR improved long run profitability, and $65 \%$ agreed that CSR provided favourable public image - and these attitudes varied significantly by sector. It was also found that the most influential factor determining attitude towards social responsibility was family upbringing. The other important factors were traditional beliefs and customs and common practice in industry. The divergence in these two studies shows the problems involved with aggregate studies: that aggregating all the Asian countries together is not that helpful, let along aggregating industries too.

\section{The Challenges Ahead}

As alluded to previously, research on CSR within Asia has do date has been limited. So many studies have been exploratory and descriptive. Arguably for the academic field to develop there needs to be a 
'step change' in the focus and quality of work, with more empirically driven theory development to evolve. There is a role here for both qualitative and quantitative, positivist and normative. Traditional 'core' disciplines such sociology, political theory, economics and psychology all have a role alongside traditional business disciplines in explaining, understanding and developing the field of CSR within Asia. In this special issue we are beginning to see this evolve.

\section{Papers in this Special Issue}

The first paper in this collection (Baughn et al.) is of a comparative nature. Like the work of Welford (2004), it not only compares countries within Asia but also compares these with a range of non-Asian countries. The findings stress the importance of the national and regional systems in which firms are embedded, particularly regarding differing underlying institutional capacities. In this context, one particular variable that is stressed in comparative CSR, particularly in explaining differences between Asia and Western CSR, is the role of religion. The second paper in this collection (Zinkin) contributes to this debate by providing a close analysis of relevant Moslem religious texts. His finding is of considerable overlap between the tenets of Islam and the concept of corporate responsibility as represented by the principles of the UN Global Compact, with the possible exception of Islam's focus on personal responsibility and non-recognition of the corporation as a legal person.

Turning to practitioner issues, a key question that companies ask is how they should engage in CSR. The third paper (Lee) looks particularly at stakeholder relations. He finds that many companies recognize the importance of substantive rather than symbolic relations but that these necessarily vary even among companies within a single sector and that senior management buy-in, the ability of companies to meet the needs of the stakeholders and clear stakeholder communications are crucial to the success of these relations. The fourth paper in the collection (Maximiano) extends this practitioner theme by pointing to the importance of institutionalizing and sustaining initial CSR commitments. It offers a model of value based leadership as a component in the integration of CSR into core business.

\section{References}

Abdul M, Ibrahim S. 2002. Executive and management attitudes towards Corporate Social Responsibility in Malaysia. Corporate Governance 2(4): I0-I6.

Aguilera R, Rupp D, Williams C, Ganapathi J. 2007. Putting the S Back in CSR: A Multi-level Theory of Social Change in Organizations. Academy of Management Review 32(4): 836-863.

Bansal P, Roth K. 2000. Why Companies Go Green: A Model of Ecological Responsiveness. The Academy of Management Journal 43(4): 7I7-736.

Bartlett CA, Ghoshal S. I989. Managing Across Borders: the Transnational Solution. Harvard Business School Press: Boston, MA.

Bi J, Krzysztof M, Yang J, Zhang B, Yuan Z, Wan Q, Wang X. 2006. New development strategy and local environmental governance in China. In Partnerships for Sustainable Development: Perspectives from the Asia-Pacific Region, Welford R, Hills P, Young W (eds). Hong Kong University Press: Hong Kong.

Birch D, Moon J. 2004. CSR in Asia. Journal of Corporate Citizenship No. I3.

Campbell J. 2007. Why would corporations behave in socially responsible ways? An institutional theory of corporate social responsibility. Academy of Management Review 32(3): 946-967.

Carroll A. I979. A three dimensional model of corporate performance. Academy of Management Review 4: 497-505.

Chakraborty S. I997. Business Ethics in India. Journal of Business Ethics 16(14): I529-1538.

Chapple W, Chambers E, Moon J, Sullivan M. 2006. National Patterns of CSR and Globalisation: Seven Countries Compared. In Partnerships for Sustainable Development: Partnerships for the Asia Pacific Region, Welford R, Hills P, Young W (eds). Hong Kong University Press: Hong Kong.

Chapple W, Gond JP, Louche C. 2006. Exploring Corporate Social Responsibilities Across Varieties of Capitalism. Presented at 2006 Academy of Management, August 11-16. Atlanta Georgia. 
Chapple W, Moon J. 2005. Corporate social responsibility (CSR) in Asia: a seven country study of CSR website reporting. Business and Society 44(4): II5-136.

Christmann P. 2004. Multinational companies and the natural environment: determinants of global policy standardization. Academy of Management Journal 47(5): 747-760.

The Economist. 2005. 22 January.

Eisenhardt K. I989. Building theories from case study research. Academy of Management Review I4: 488-5II.

Forsyth T. 2005. Enhancing climate technology transfer through greater public-private cooperation: lessons from Thailand and the Philippines. Natural Resource Forum 29(2): $165-176$.

Fukukawa K, Moon J. 2004. A Japanese model of corporate social responsibility?: a study of website reporting. Journal of Corporate Citizenship I6: 45-59.

Habisch A, Wegner M, Schmidpeter R, Jonker J. 2005. Corporate Social Responsibility Across Europe. Springer Berlin Heidelberg.

Hills P, Welford R. 2006. Ecological modernisation and corporate environmental governance in Hong Kong. In Partnerships for Sustainable Development: Perspectives from the Asia-Pacific Region, Welford R, Hills P, Young W (eds). Hong Kong University Press: Hong Kong.

Husted B, Allen D. 2006. Corporate social responsibility in the multinational enterprise: strategic and institutional approaches. Journal of International Business 37: 838-849.

Kemp M. 200I. Corporate Social Responsibility in Indonesia: Quixotic Dream or Confident Expectation? Technology, Business and Society Programme Paper, Number 6, United Nations Research Institute for Social Development.

Lines V. 2004. Corporate reputation in Asia: looking beyond bottom-line performance. Journal of Communication Management 8(3): $233-245$.

Lockett A, Moon J, Visser W. 2006. Corporate social responsibility in management research: focus, nature, salience and sources of influence. Journal of Management Studies 43: II7-136.

Logsdon J, Wood D. 2005. Global business citizenship and voluntary codes of ethical conduct. Journal of Business Ethics 59: $55^{-67 .}$

Lucas R, Wheeler D, Hettige H. I992. Economic Development, Environmental Regulation and the International Migration of Toxic Industrial Pollution I960-I988. World Bank Discussion Paper.

Maignon I, Ralston D. 2002. Corporate Social Responsibility in Europe and the US: Insights from Businesses' SelfPresentations. Journal of International Business Studies 33(3): 497-5I4.

Matten D, Moon J. In press. 'Implicit' and 'explicit' CSR: a conceptual framework for a comparative understanding of corporate social responsibility. Academy of Management Review.

Mohan A. 200I. Corporate citizenship: perspectives from India. Journal of Corporate Social Citizenship 2: I07-II7.

Moon J, Crane A, Matten D. 2004. Can corporations be citizens: corporate citizenship as a metaphor for business participation in society. Business Ethics Quarterly 15(3): 429-454.

Perry M, Singh S. 2002. Corporate environmental responsibility in Singapore and Malaysia: the potential limits of voluntary initiatives. In The Greening of Business in Developing Countries: Rhetoric, Reality and Prospects, Utting P (ed.). UNRISD: New York.

Prahalad C, Doz Y. 1987. Balancing Local Demands and Global Vision. Collier Macmillan.

Sison A, Palmer-Angeles A. 1997. Business Ethics in the Philippines. Journal of Business Ethics I6(I4): I519-1528.

Snell R, Tseng C. 2002. Moral Atmosphere and Moral Influence under China's Network Capitalism. Organization Studies 23(3): 449-478.

Strike V, Gao J, Bansal P. 2006. Being good while being bad: social responsibility and the international diversification of US firms. Journal of International Business Studies 37: 850-862.

Teoh H, Thong G. I984. Another Look at Corporate Social Responsibility and Reporting: An Empirical Study in a Developing Country. Accounting, Organizations and Society 9: 189-206.

Viere T, Herzig C, Schaltegger S, Leung R. 2006. Partnerships for Sustainable Business Development: Capacity Building in South East Asia. In Partnerships for Sustainable Development: Perspectives from the Asia-Pacific Region, Welford R, Hills P, Young W (eds). Hong Kong University Press: Hong Kong.

Welford R. 1997. Highjacking Environmentalism: Corporate Responses to Sustainable Development. Earthscan: London.

Welford R. 2004. Corporate social responsibility in Europe and Asia: critical elements and best practice. Journal of Corporate Citizenship I4: 3I-47.

Welford R. 2005. Corporate social responsibility in Europe, North America and Asia. Journal of Corporate Citizenship I7: 33-53.

Wood D. I99I. Corporate Social Performance Revisited. Academy of Management Review I6(4): 69I-7I8.

Wu C. 200I. The study of global business ethics in East Asia: Taiwanese enterprises in Indonesia as targets. Omega 29: 22I-23I.

Yip G. I992. Total Global Strategy: Managing for Worldwide Competitive Advantage. Prentice-Hall: Englewood Cliffs, NJ. 